\title{
Hypoxia Pathway Proteins are Master Regulators of Erythropoiesis
}

\author{
Deepika Watts ${ }^{1}$, Diana Gaete ${ }^{1}\left[\right.$, Diego Rodriguez ${ }^{1}$, David Hoogewijs ${ }^{2}$, Martina Rauner ${ }^{3}$, \\ Sundary Sormendi ${ }^{1}$ and Ben Wielockx ${ }^{1, *}$ (i)
}

1 Institute of Clinical Chemistry and Laboratory Medicine, Technische Universität Dresden, 01307 Dresden, Germany; deepika.watts@ukdd.de (D.W.); Diana.Gaete@ukdd.de (D.G.); diego.rodriguez@mailbox.tu-dresden.de (D.R.); sundary.sormendi@ukdd.de (S.S.)

2 Section of Medicine, Department of Endocrinology, Metabolism and Cardiovascular System, University of Fribourg, 1700 Fribourg, Switzerland; david.hoogewijs@unifr.ch

3 Department of Medicine III and Center for Healthy Aging, Technische Universität Dresden, 01307 Dresden, Germany; Martina.Rauner@uniklinikum-dresden.de

* Correspondence: ben.wielockx@tu-dresden.de; Tel.: +49-351-458-16260

Received: 3 October 2020; Accepted: 28 October 2020; Published: 30 October 2020

\begin{abstract}
Erythropoiesis is a complex process driving the production of red blood cells. During homeostasis, adult erythropoiesis takes place in the bone marrow and is tightly controlled by erythropoietin (EPO), a central hormone mainly produced in renal EPO-producing cells. The expression of EPO is strictly regulated by local changes in oxygen partial pressure $\left(\mathrm{pO}_{2}\right)$ as under-deprived oxygen (hypoxia); the transcription factor hypoxia-inducible factor-2 induces EPO. However, erythropoiesis regulation extends beyond the well-established hypoxia-inducible factor (HIF)-EPO axis and involves processes modulated by other hypoxia pathway proteins (HPPs), including proteins involved in iron metabolism. The importance of a number of these factors is evident as their altered expression has been associated with various anemia-related disorders, including chronic kidney disease. Eventually, our emerging understanding of HPPs and their regulatory feedback will be instrumental in developing specific therapies for anemic patients and beyond.
\end{abstract}

Keywords: hypoxia; erythropoiesis; EPO; HIF; CKD

\section{Introduction}

Red blood cell $(\mathrm{RBC})$ production mainly takes place in the bone marrow during homeostasis. This process encompasses a number of proliferation and differentiation steps, starting at the hematopoietic stem cell (HSC) and down to specialized erythroid progenitors, finally turning into mature RBCs. The complex process of erythropoiesis is vastly intertwined with iron metabolism [1] and regulated by a number of cytokines, including the central glycoprotein hormone erythropoietin (EPO). The primary producers of EPO are specialized fibroblast-like peritubular cells located in the adult kidney or fetal hepatocytes. Nevertheless, more recent studies have also reported EPO production in astrocytes, osteoblasts, and pericytes upon transcriptional response, dependent on the hypoxia pathway [2-6]. Our initial understanding of this pathway came into light almost 30 years ago when the group of Dr. Semenza identified hypoxia-inducible factor (HIF) as a transcription factor responsible for the expression of EPO [7,8]. Hence, increased EPO during diminished oxygen supply, for instance, at high altitude, causes our body to make more RBCs to augment the delivery of oxygen. Since then, numerous hypoxia pathway proteins (HPPs) have been identified in different cells of our body, often playing critical roles in survival, growth, and differentiation upon changes in $\mathrm{pO}_{2}$ [9]. Cellular oxygen sensing is, therefore, a fundamental biological process that is necessary for the adaptation of 
living organisms to changing physiological and pathological situations. To date, a limited amount of enzymes, three HIF prolyl hydroxylase domain proteins (PHD1-3), and factor-inhibiting HIF (FIH) have been identified as oxygen sensors. These oxygen-dependent enzymes act as hydroxylases and dioxygenases, regulating the availability of $\mathrm{HIF} \alpha$ subunits, and, in turn, define when and how cells express genes in response to changing $\mathrm{pO}_{2}$ [10-12]. Under hypoxia, when the oxygen sensors are inactive, HIF $\alpha$ subunits are stabilized and translocate to the nucleus and bind to HIF $\beta$ and a number of other cofactors. Subsequently, the HIF-complex binds hypoxia response elements (HREs) in the promoter/enhancer of a selection of genes, generally increasing their transcription [13-15]. This review will give a more indepth view on the role of HPPs (i.e., HIF $\alpha$, PHDs, HIF-controlled genes) regulating the multistage process of erythropoiesis and discusses the current therapeutic approaches interfering with the hypoxia pathway in the treatment of anemia and/or chronic kidney disease (CKD) [16].

\section{HIF Transcription Factors and Their Modulators}

The heterodimeric HIF-complex is a key transcription factor constituted of an $\alpha$ subunit and a $\beta$ subunit. The latter, also referred to as aryl hydrocarbon receptor nuclear translocator (ARNT), is constitutively expressed, whereas HIF $\alpha$ (i.e., HIF $1 \alpha$, HIF $2 \alpha$ (also known as endothelial PAS domain containing protein 1 (EPAS1), and HIF3 $\alpha$ ) is synthesized and constantly degraded during normoxia. Degradation of the HIF $\alpha$ subunits is tightly regulated by three PHDs (also known as EGL-9 homolog EGLN2, EGLN1, and EGLN3, respectively) that hydroxylate two specific proline residues (Pro402/Pro564 in HIF1 $\alpha$ and Pro405/Pro531 in HIF2 $\alpha$ ) in the oxygen-dependent degradation domain [11,17-19]. Consequently, this hydroxylation leads to von Hippel-Lindau tumor suppressor protein (VHL) mediated ubiquitination and proteasomal degradation of the HIF $\alpha$ subunits $[12,19,20]$.

Although a recent in vitro study demonstrated that HIFs are the only targets of the PHDs [21], each PHD has a different affinity for a particular HIF subunit: HIF $2 \alpha$ is mainly regulated by PHD1, PHD2 is the major regulator of HIF1 $\alpha$ [22,23]. Noteworthy, PHD2 is the most widely expressed PHD isoform, being of crucial importance during development. Indeed, early studies in mice reported that PHD2 deficiency results in embryonic lethality between E12.5 and E14.5 due to defects in the developing placenta and heart [24,25]. Conversely, PHD1 and PHD3 deletions are not lethal and only have a limited tissue-specific impact, as exhibited by their effect on cellular metabolism in skeletal muscle and altered blood pressure in the central nervous system, respectively [26,27]. Moreover, PHD2 differs from PHD1 and PHD3 in its N-terminal zinc finger, which favors the recruitment of HSP90 machinery, facilitating HIF $\alpha$ hydroxylation [28,29]. In turn, PHD1 and PHD3 can also be regulated by hypoxia-inducible E3 ubiquitin ligases-the SIAH proteins [30]. HIF $\alpha^{\prime}$ s availability can be further modulated at the transcriptional level through crosstalk with other signaling pathways and epigenetic regulators. For instance, nuclear factor $\kappa \mathrm{B}(\mathrm{NF} \kappa \mathrm{B})$ and signal transducer and activator of transcription 3 (STAT3) have been shown to bind the HIF1 $\alpha$ promoter and induce its transcription $[31,32]$

Whereas HIF $1 \alpha$ is expressed ubiquitously, HIF2 $\alpha$ is more restricted to specific cell types like endothelial cells, cardiomyocytes, hepatocytes, adipocytes, neurons, and interstitial cells and glomeruli of the kidney [21,33-37]. Even though both HIFs regulate many common genes, their transcriptional targets often differ, as well as their kinetics of activation and oxygen dependence. Overall, gene expression and chromatin immunoprecipitation assays showed that both HIF1 $\alpha$ and HIF $2 \alpha$ are responsible for regulating the transcription of more than a thousand genes during the adaptive response to hypoxia [38-40].

Conversely, hypoxia has also been reported to suppress the expression of a number of genes by activation of transcriptional repressors or epigenetic regulators. The hypoxia-mediated gene suppression can be either HIF-dependent or HIF-independent. For instance, Cavadas and colleagues recently showed that hypoxia-mediated HIF-independent nuclear translocation of repressor element 1-silencing transcription factor (REST) is responsible for regulating $20 \%$ of hypoxia-repressed genes in hypoxia [41]. The other transcriptional repressors induced by hypoxia in a HIF-dependent manner include DEC1, DEC2, ID2, Zeb1, and Zeb2, as reviewed by Cavadas et al. [42]. Hypoxia also regulates 
epigenetic factors, such as DNA methylation and histone acetylation; those, in turn, regulate the hypoxia-responsive gene expression [43]. In addition, several recent studies, including ours, have pointed towards HIF-mediated suppression by microRNAs [44-48]. Interestingly, there is two-way communication between HIFs and microRNAs, as the latter have also been suggested to control the expression of HIFs in different cell types [49,50] (recently reviewed by Serocki and colleagues [46]).

Soon after their discovery, PHDs have been considered to play a distinctive role in regulating erythropoiesis. Somatic inactivation of PHD2 after birth causes a significant rise of serum EPO levels, an effect that can only be mimicked by the simultaneous deletion of PHD1 and PHD3. Importantly, we and others discovered that this phenotype is exclusively dependent on HIF $2 \alpha$ since its targeted deficiency, but not that of HIF1 $\alpha$, reverses this phenotype [51,52]. Briefly, severe HIF2-driven EPO production resulted in nonlethal hematocrit levels up to 85\% upon PHD2 deletion in CD68-expressing cells, including renal EPO-producing cells (REPCs) [34]. In humans, various heterozygous point mutations have been described in the PHD2 gene, resulting in an increase of red blood cell mass, hemorrhages, strokes, and an enhanced risk of thrombosis [53-55]. The mutations P317R and P371H affect the substrate binding of PHD2, partially inhibiting the hydroxylation of HIF [56]. Interestingly, a patient with a heterozygous H374R mutation developed a recurrent paraganglioma that exhibited loss of PHD2 in both alleles in addition to the erythrocytosis [53].

Next to EPO and its receptor, several other genes involved in the process of erythropoiesis are directly or indirectly regulated by the PHD/HIF axis. These include genes implicated in iron metabolism, such as transferrin (Tf), transferrin receptor-1 (Tfr-1), ferroportin (Fpn), hepcidin, divalent metal transporter 1 (DMT1), duodenal cytochrome b (DCYTB), and GATA-1 [56-61], granting this axis a central role during anemic processes associated to a wide range of diseases (Figure 1). The regulation of various genes involved in the erythropoiesis regulated by hypoxia or HPPs is summarized in Table 1.

Table 1. Regulators of erythropoiesis.

\begin{tabular}{|c|c|c|c|c|}
\hline $\begin{array}{l}\text { Stage of Erythropoiesis/ } \\
\text { Iron Metabolism }\end{array}$ & Factors & Key Role in Erythropoiesis & Regulation by HIF/EPO & References \\
\hline $\begin{array}{l}\text { Early stages of development of } \\
\text { erythroid progenitors }\end{array}$ & GATA-1 & $\begin{array}{l}\text { Initiates erythropoiesis Regulates the } \\
\text { transcription of several erythroid } \\
\text { differentiation-related genes }\end{array}$ & $\begin{array}{l}\text { HRE present in GATA-1 and } \\
\text { GATA-1 regulation by HIF1. } \\
\text { EPO protects GATA- } 1 \text { from } \\
\text { caspase-induced degradation }\end{array}$ & [62-65] \\
\hline \multirow{2}{*}{ Pro-erythroblasts to late erythroblasts } & EPO & $\begin{array}{l}\text { Key cytokine essential for growth, } \\
\text { survival, and differentiation of RBC's }\end{array}$ & HIF2 directly regulates EPO & {$[52,66-68]$} \\
\hline & EPOR & $\begin{array}{l}\text { Essential for erythropoiesis and action } \\
\text { of EPO }\end{array}$ & $\begin{array}{l}\text { Some evidence on regulation by } \\
\text { hypoxia and HIFs }\end{array}$ & [69-71] \\
\hline Late stage maturation/Apoptosis & FAS, FAS-L & Apoptosis and arrest maturation & Downregulation by EPO & [72] \\
\hline \multirow{6}{*}{ Iron metabolism } & Hepcidin & $\begin{array}{l}\text { A crucial regulator of iron } \\
\text { metabolism; suppresses ferroportin }\end{array}$ & $\begin{array}{l}\text { Direct and indirect suppression by } \\
\text { hypoxia, HIF, and EPO }\end{array}$ & [73-77] \\
\hline & Ferroportin (FPN) & $\begin{array}{l}\text { A critical factor that facilitates iron } \\
\text { export from the cells }\end{array}$ & Regulated by HIF2a and hepcidin & [78] \\
\hline & $\begin{array}{l}\text { Erythroferrone } \\
\text { (ERFE) }\end{array}$ & Suppresses hepcidin production & Upregulation by EPO & {$[79,80]$} \\
\hline & Transferrin (TF) & Required for transporting iron & Regulation by HIF1 & [61] \\
\hline & $\begin{array}{c}\text { Transferrin } \\
\text { receptor (TFR1) }\end{array}$ & $\begin{array}{l}\text { Plays role in erythroid differentiation/ } \\
\text { role in iron uptake }\end{array}$ & Induced by HIF1 and hypoxia & {$[59,60]$} \\
\hline & FGF-23 & $\begin{array}{l}\text { Potential role in erythropoiesis. } \\
\text { blockage of FGF- } 23 \\
\text { results in increased erythropoiesis }\end{array}$ & Increased by EPO & {$[66,81-83]$} \\
\hline
\end{tabular}




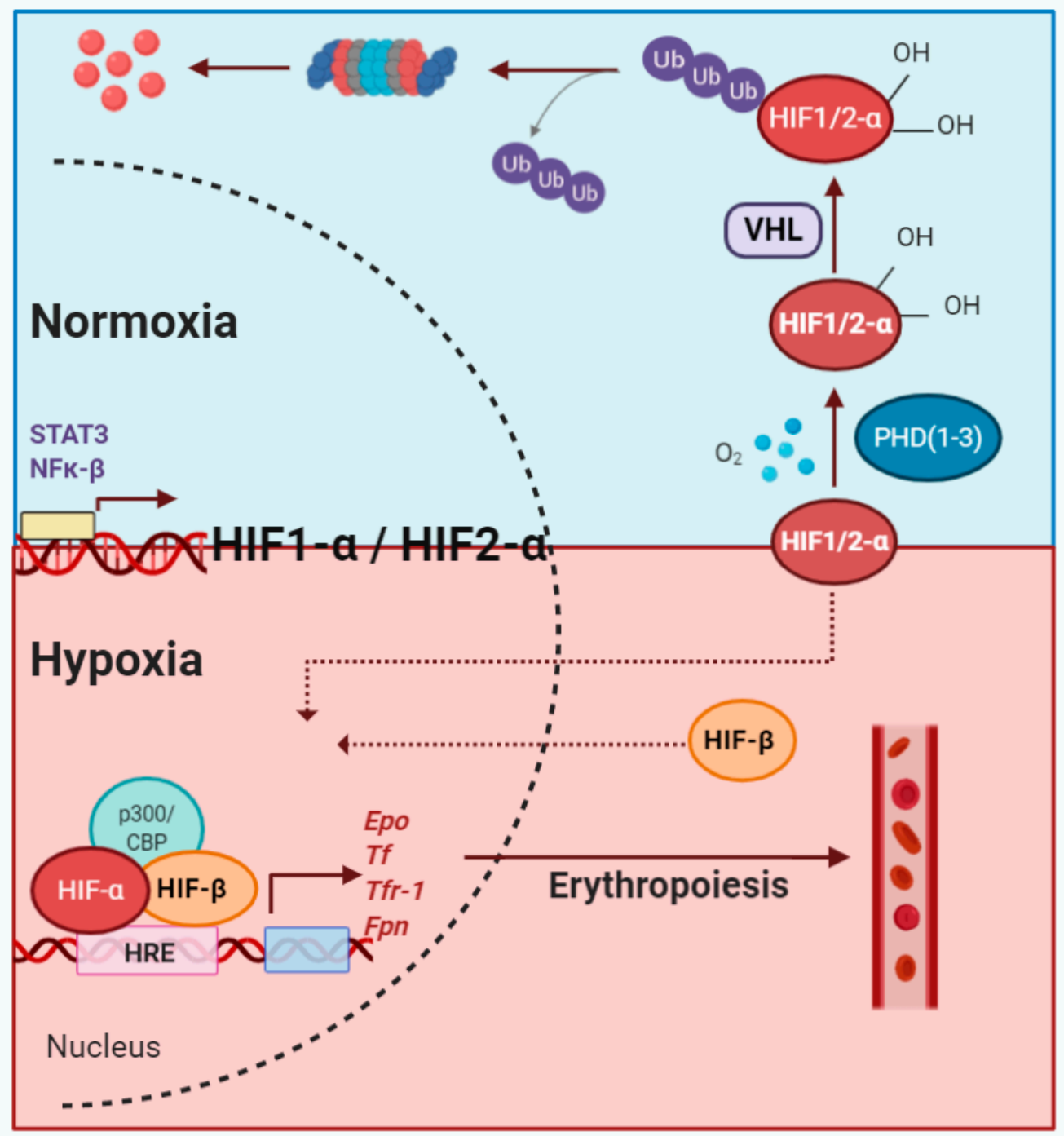

Figure 1. Schematic overview of the hypoxia pathway under normoxia and hypoxia. The hypoxia-inducible factor (HIF)- $\alpha$ subunits are synthesized and subsequently degraded under normoxia (blue). In the presence of physiological oxygen levels, prolyl hydroxylase domain proteins (PHDs) mediate hydroxylation of HIFs, leading to subsequent binding to von Hippel-Lindau tumor suppressor protein (VHL). VHL facilitates the ubiquitination of hydroxylated HIFs, resulting in proteasomal degradation. However, under hypoxia (red), the hydroxylation of the alpha subunits is inhibited, stabilizing the HIF- $\alpha$ subunits. The stabilized alpha subunits bind to the beta subunit and translocate to the nucleus. The HIFs, together with other cofactors, bind hypoxia response elements (HREs), promoting the transcription of genes essentially involved in erythropoiesis. Created with Biorender.com.

\section{Erythropoiesis: A Multistep Process}

On average, $200 \times 10^{9} \mathrm{RBC}$ are generated and released into circulation every day [64]. This production is adjusted on a need basis and is tightly controlled by complex networks involving HPPs, regulators of iron metabolism, and erythropoietic stress [1,84-86]. Erythropoiesis is a multistep process that includes numerous proliferation and differentiation stages, starting from the HSC and down to committed erythroid progenitors and different erythroblast populations in the bone marrow (BM). This eventually gives rise to reticulocytes and enucleated mature RBCs in the blood $[7,64,87]$. The course of this development includes strict control by a number of transcription factors and epigenetic regulators. GATA- 1 is the major transcription factor regulating the differentiation and survival of erythroid progenitors [63,88-90], including genes involved in heme and/or globin synthesis, 
antiapoptosis, cell cycle regulators, and the erythropoietin receptor (EPOR) [88-94]. In turn, GATA-1 is also regulated by HIF $[62,93,95]$. Additionally, GATA- 2 is essential for the regulation of lineage-restricted gene expression during erythroid differentiation $[63,96]$. Other erythropoietic regulators that have been studied in the context of hypoxia and HPPs are interleukin-3, certain vitamins, and transferrin (TF)-transferrin receptors (TFR) modulating iron metabolism [59-61].

Several studies in the field of erythropoiesis have also explored the role of micro-RNAs, including during the process of enucleation [65,97-99]. A recent study by Rivkin and colleagues reported that the hematopoietic-specific mir-142 plays a critical role in maintaining the typical biconcave shape of RBCs through the control of cytoskeletal regulators and directly influencing the overall lifespan of the erythrocyte [100]. In another study, mir-142 was shown to target HIF1 $\alpha$ directly [101]. Although more research is required to unambiguously link mir-142, HIF1 $\alpha$, and the shape of the RBCs, other studies have reported HIF's participation in the regulation of micro-RNAs involved in different stages of erythropoiesis [65,98,102,103] (Table 1).

\section{EPO/EPOR Axis: Hypoxia Pathway in Action}

EPO is the central hormone during erythropoiesis and is mainly responsible for survival, proliferation, and differentiation of committed progenitors, ultimately enhancing the oxygen-carrying capacity of blood [104]. EPO promotes the survival of colony-forming unit-erythroid cells (CFU-E) and early erythroblasts. Moreover, erythroid precursors are differentially sensitive to EPO and respond differently to increasing levels. At higher levels, cells survive and differentiate, whereas at lower EPO levels, less sensitive cells die due to caspase-mediated apoptotic death [91].

After birth, EPO is mainly produced by REPCs, whereas hepatocytes are the main source during embryo development [105-111]. In the BM, EPO binds to its homodimeric receptor EPOR on erythroid progenitor cells, triggering its association with Janus kinase (JAK2). In turn, JAK2 phosphorylates the cytoplasmic tail of EPOR, providing multiple docking sites for signal-transducing proteins, which subsequently lead to STAT-5 phosphorylation [106]. Additionally, it was shown that the phosphatidylinositol-3-kinase/protein kinase B (PI-3k/AKT) and mitogen-associated protein kinase/extracellular signal-related kinase (MAPK/ERK) pathways can also be activated in this way [105].

Severe hypoxia or loss of PHD2 in hepatocytes can also result in dramatic liver EPO production in adults [68,111-113]. However, in contrast to HIF2 $\alpha$-mediated EPO production, HIF stabilization in the epithelial cells of the kidney results in suppression of EPO, leading to anemia. The lab of Dr. Haase showed that proximal nephron-specific deletion of VHL (Pax8-rtTA-cre) results in a reduction of REPCs and renal anemia, suggesting cellular crosstalk in the tubule-interstitial compartment in the kidney, changing the production of EPO [114].

Since HIF2 $\alpha$ is a major player in erythropoiesis, most of the studies have focused on this subunit as a facilitator of EPO production. Interestingly, HIF3 $\alpha$ was also recently shown to be involved in EPO regulation [115-117]. Until now, only limited studies have provided insight into the complex alternative splicing of $H I F 3 \alpha$ mRNA, resulting in short and long variants either inhibiting the hypoxia response or possessing transactivation capacities [116,118]. In vitro knockdown or overexpression of the long HIF-3 $\alpha-2$ splice variant in EPO-producing cell lines resulted in the downregulation or upregulation of EPO, respectively, involving the canonical HRE $[115,116]$. However, further research is required to define whether HIF3-mediated EPO regulation also occurs in vivo.

Whereas HIF2 dependent EPO regulation is well-established, the precise molecular mechanism responsible for tight expression control and the regions within the EPO locus that are responsive to HIF-mediated regulation remain the subject of continuous research efforts. It is known that oxygen-dependent regulation of the EPO gene is controlled by distinct regulatory sequences in the liver and kidney and involves a region of $0.4 \mathrm{~kb}$ of the $5^{\prime}$-sequence (promoter) and a $0.7 \mathrm{~kb}$ region of the $3^{\prime}$-sequence in the liver $[9,119]$ whereas a highly conserved regulatory element responsible for renal EPO expression has been suggested to be located between 14 and $6 \mathrm{~kb}$ in the $5^{\prime}$-region [120,121]. However, the strict tissue-specific and conditional EPO transcriptional regulation strongly suggests that additional 
mechanisms might be involved. Moreover, studies on a single gene scale [122] and at the pangenomic level [123] showed that long-range enhancer-promoter chromatin looping occurs independently of HIF and involves the recruitment of transcriptional factors and coactivators, further suggesting that EPO regulation might be more complex. Accordingly, Smythies et al. [40] illustrated that the tissue-specific role of HIF $2 \alpha$ is related to association with tissue-specific transcription factors. More recently, Orlando et al. reported that multiple distal and proximal HREs cooperate in oxygen-regulated EPO gene expression and that EPO regulation in renal cells may have more in common with neuronal cells than with hepatic cells, further illustrating the context-dependent complexity of EPO regulation [124].

\section{Hypoxia-Mediated EPO Production at Other Sites}

Apart from REPCs and embryonic hepatocytes, other cell types have also been shown to produce $\mathrm{EPO}$ in response to hypoxia. As an example, hypoxia-induced EPO production in the brain and certain cell types of the central nervous system (CNS) have come to light in the past years $[125,126]$. Urrutia and colleagues showed that pericyte specific (NG2:cre) VHL or PHD2/PHD3 deficiency leads to polycythemia. This was reversed in mice that were additionally lacking HIF $2 \alpha$, emphasizing the essential role of HIF $2 \alpha$ for EPO production in other cell types $[5,125,127]$. Rankin and colleagues showed that specific deletion of VHL in osteoprogenitors in mice (OSX:cre-VHLf/f) presented elevated EPO expression in bone, which was also accompanied by polycythemia. Additionally, in this setting, HIF $2 \alpha$ was the central HIF isoform [4].

It is noteworthy that the majority of EPO-producing cells, such as pericytes, astrocytes, as well as REPCs, are of neurological origin $[5,6,52,128]$. Recent unpublished data from our lab also described EPO production in the adrenal gland chromaffin cells upon HIF2 $\alpha$ activation, cells known to be derived from the neural crest. In line with this, polycythemia is one of the initial traits recognized in pheochromocytoma (the tumor of the adrenal medulla) relate to VHL or loss-of-function mutations or HIF2 gain-of-function mutations [67]. In addition to HIF-mediated increased EPO expression in tumors, EPOR is also significantly increased in the hypoxic region of tumors, suggesting a HIF-mediated modulation of EPOR [69,129].

\section{EPOR and HIF Axis}

EPO will bind to erythroid progenitors (i.e., erythroblasts) in the BM/spleen via the EPOR to meet the enormous daily production of RBCs. Remarkably, an in silico study identified almost thirty genetic variants of the EPOR and seven variants of the EPO gene associated with erythrocytosis or increased hematocrit in humans. Mutations in EPOR have been shown to activate the receptor constitutively, resulting in enhanced production of erythroid colonies and erythrocytosis but reduced EPO synthesis [130].

In addition to its expression on erythroblasts, EPOR has even been identified on nonerythroid cells such as neural cells, endothelial cells, skeletal muscle myoblasts, macrophages, and white adipose tissue [131-133]. Although under normal conditions, EPOR expression is very low in the nervous system, mild episodes of hypoxia can significantly increase its expression [70]. Similarly, unpublished data from our lab suggest HIF-mediated EPOR expression in the adrenal medulla.

Furthermore, Su and colleagues recently showed that hypoxia induces EPOR expression via HIF1 $\alpha$ in lung carcinoma cells. According to this study, HIF1 $\alpha$ interacts with the transcription factor early growth response 1 (EGR1) to negatively regulate EPOR in the early phase of hypoxia, and with SP1 to promote EPOR expression in the later phase [69]. Thus, the hypoxia pathway is crucial in modulating the expression of EPO and its receptor. Both are not only directly involved in erythropoiesis; EPO is also crucial in the regulation of the iron metabolism via hepcidin suppression [80] as discussed further in the review. 


\section{Iron Metabolism: HPP as Cucial Contributors}

Hemoglobin is the most essential component of erythrocytes as it carries oxygen bound to heme groups throughout the body. Central in heme is iron, which makes up about $70 \%$ of all available iron. Therefore, iron transport and metabolism are of utmost importance and, in turn, are also regulated by a number of HRE-containing genes, directly linking it to the hypoxia pathway [134]. For instance, to maintain necessary iron levels in other cells, HIF $2 \alpha$ plays a pivotal role in promoting cellular iron uptake. Particularly, HIF2 $\alpha$ upregulates divalent metal transporter 1 (DMT1) and duodenal cytochrome $\mathrm{b}$ (DCYTB), where DMT1 is responsible for iron transport into cells, while DCYTB reduces the ferric form of iron to ferrous iron $[135,136]$. HIFs also regulate the expression of transferrin (TF) and transferrin receptor-1 (TFR-1), where TF catches up to two iron atoms from circulation and transports it into the cells via TFR-1 $[60,61,137,138]$. FPN, a critical factor that facilitates iron export from iron-storing cells (i.e., enterocytes and macrophages), is inhibited by the peptide hormone hepcidin [139]. Therefore, it is crucial that hepcidin production is strictly controlled for normal erythropoiesis to occur. To ensure this, erythroblasts produce and secrete the hormone erythroferrone (ERFE) upon EPO signaling, suppressing hepcidin production $[77,79,80,138,140,141]$. A more recent study by Arezes and colleagues suggests direct interaction of ERFE with BMP5, BMP6, and BMP7, leading to the inhibition of BMP/SMAD signaling and consequent hepcidin suppression [79] (Figure 2 and Table 1). More detailed insights into the regulation and action of ERFE have been recently reviewed by Coffey and Ganz [140].

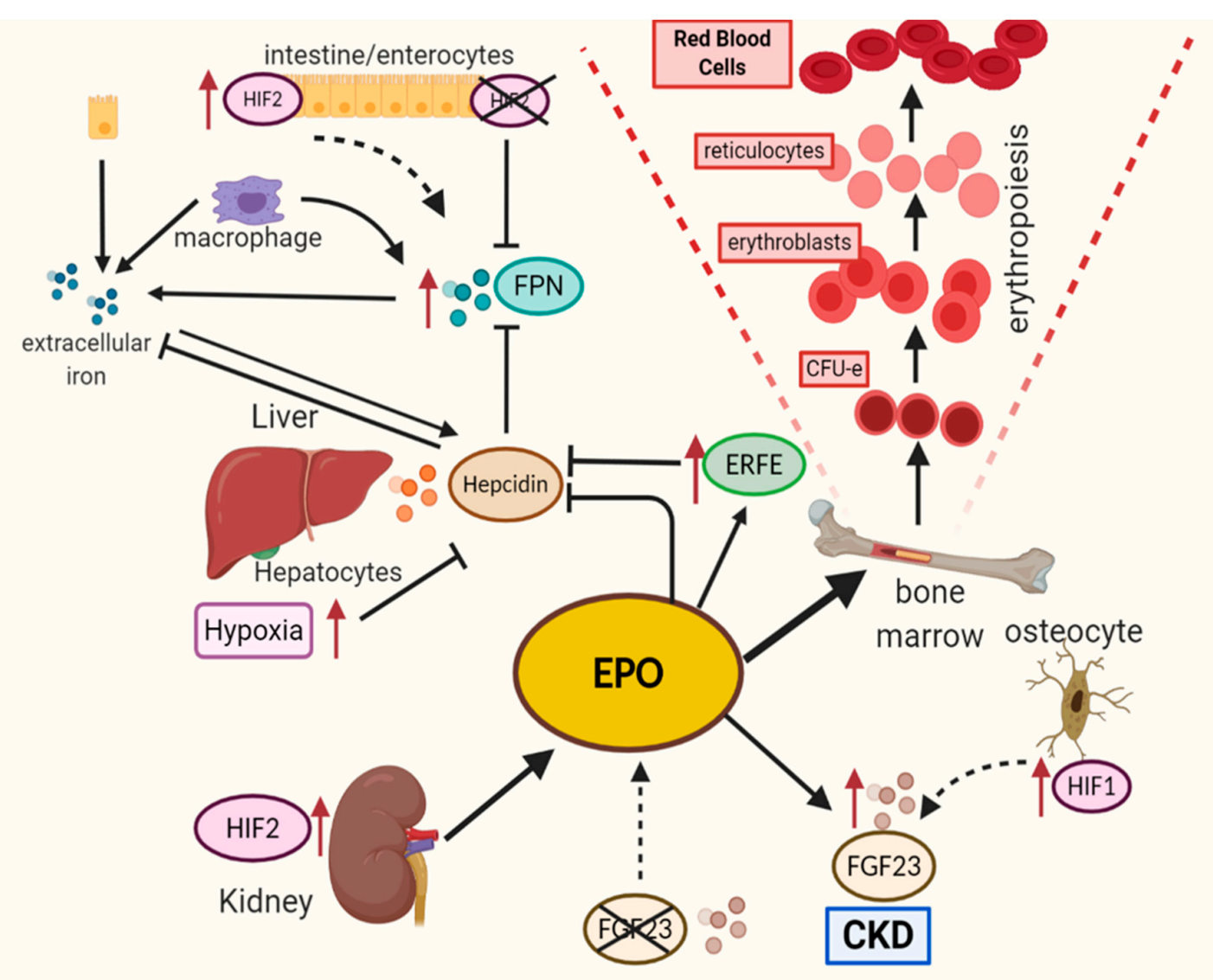

Figure 2. Hypoxia pathway proteins mediated regulation of erythropoiesis. EPO, the crucial factor involved in erythropoiesis, is mainly HIF2-dependently regulated in the kidney. EPO produced in the kidney acts on erythroblasts in BM via EPOR and is essential in the development of red blood cells, especially in the late phases. In addition to its crucial role in the development of RBCs, iron metabolism is indispensable. More information can be found in the text. Created with Biorender.com. 
Interestingly, hepcidin functionality has been linked to HIF2 $\alpha$ activity $[75,78]$. Initial studies have pointed towards a direct role of HPP during hepcidin production, where hypoxia inversely regulates hepcidin expression [142] by downregulating the cyclic AMP response element-binding protein $\mathrm{H}$ (CREB-H), mediated by platelet-derived growth factor (PDGF-BB) [74] or direct suppression of hepcidin by HIF binding to HRE, and suppressing HAMP (encoding hepcidin) transcription [143]. Vice versa, the deletion of hepatic hepcidin significantly increased FPN, leading to cellular iron efflux, decreased PHD activity, and, eventually, HIF2 $\alpha$ upregulation [75].

Further, a negative feedback loop of EPO by increased iron levels has been proposed. Iron excess, induced by injection or feeding, resulted in decreased renal EPO gene expression, which is mediated through reduced HIF $2 \alpha$ levels in renal interstitial fibroblasts [144]. In addition to regulation by PHDs, translational regulation of HIF $2 \alpha$ is inhibited by binding of iron regulatory proteins (IRPs) on iron response element (IRE) in its 5'UTR $[113,145]$. Taken together, these studies suggest a Fe-HIF2 $\alpha$-EPO-ERFE-hepcidin axis, underlining the importance of HIF2 $\alpha$ in iron metabolism $[75,146,147]$. PHDs and HIFs can be potentially targeted for the treatment of iron-related disorders such as anemia, chronic kidney disease (CKD), and polycythemia, whereas HIF2 $\alpha$ is an essential target for polycythemia-related disorders [106].

Chronic kidney disease (CKD) is one of the leading causes of death and arises mainly as a result of diabetes and hypertension [148]. Although anemia can be caused by a large variety of reasons, anemia due to kidney damage is attributed to decreased production of EPO by the kidneys, leading to suppression of erythropoiesis [107]. HIF stabilizers act by restoring EPO levels and reducing hepcidin and have been used effectively to enhance hemoglobin levels in patients suffering from anemias, including CKD patients [149].

\section{Anemia and CKD-The PHD-HIF Axis and Therapeutic Targeting}

Anemia can have different etiologies and is a common feature during the course of numerous pathologies. As such, the success of specific anemia treatments depends on the disease context. In many cases, including CKD-related anemia, treatment includes erythropoiesis-stimulating agents (ESA) [91]. However, there is not always a clear inverse correlation between the degree of anemia and EPO levels in the serum. In fact, many patients suffering from renal anemia do not respond to treatment with ESA [82]. Together, this suggests that modulating EPO levels in serum is not sufficient to treat anemia in CKD patients and that new therapeutic approaches need to be developed. In line with this, a recent study showed that anemia in rats led to increased expression of HIF $2 \alpha$ and EPO in kidney and bone marrow, whereas rats suffering from CKD failed to show these increases.

An important factor contributing to the progression of CKD is incomplete or maladaptive tissue repair following acute kidney injury (AKI). In this setting, HIF stabilization through pharmacological PHD inhibitors enhances kidney recovery in several types of AKI, including AKI caused by nephrotoxicity and renal reperfusion, the most common causes of AKI. Importantly, other studies suggest that HIF1 $\alpha$ accumulation might be harmful during sepsis-associated AKI. This indicates that the success of HIF stabilization depends on the type of AKI and, possibly, also other factors [150].

Since PHDs need 2-oxoglutarate (2-OG) for their hydroxylase activity, most of the clinically advanced HIF stabilizers are 2-OG derivatives (reviewed by [151]). To date, several drugs that inhibit PHD activity have progressed into clinical trials. Importantly, these drugs do not target FIH, which preferentially inhibits HIF $1 \alpha$ transcriptional activation, allowing for increased HIF $2 \alpha$ stabilization. HIF stabilization induces a transient increase in EPO levels, achieving concentrations closer to the physiological range than those obtained with current ESA therapy. This suggests that treatment with HIF stabilizers could be more suited for certain patients (for recent reviews, see [152-155]. Despite the promising future HIF stabilizers hold for the treatment of anemia in CKD patients, concerns have arisen regarding their chronic use because of the significant pool of genes targeted by HIFs as well as the higher risk of hyperkalemia or the development of iron deficiency $[152,156,157]$. Therefore, 
further research is of utmost importance to better understand the impact of long-term HIF stabilization and to identify drugs targeting HIF $1 \alpha$ and/or HIF $2 \alpha$ isoforms specifically.

\section{HIF-EPO-FGF-23 Axis: PHD2/HIF Inhibition}

As discussed above, HIF-dependent EPO regulation is crucial for appropriate erythropoiesis in homeostatic and pathological conditions. Considering that adult erythropoiesis occurs in BM, it is noteworthy to mention another important player in this axis: fibroblast growth factor-23 (FGF-23). FGF-23 is a bone-derived hormone essential for regulating vitamin $D$ and phosphate concentrations [158]. Two forms of FGF-23 have been described: a full-length biologically active protein (iFGF-23) that, upon cleavage, results in a C-terminal inactive fragment (cFGF-23) [159,160]. While iFGF-23 interacts with FGF receptor 1 (FGFR1) to decrease blood phosphate levels in mice, cFGF-23 can directly increase BM erythroid cell numbers in the same manner as treatment with recombinant human (rhEPO) [82]. Accordingly, FGF-23 constitutes the link between erythropoiesis and bone homeostasis in both physiological as well as in a variety of pathological conditions [161,162]. Indeed, we recently showed that increased FGF-23 levels are associated with ineffective erythropoiesis and impaired bone mineralization in myelodysplastic syndromes (MDS) [159]. Similarly, in CKD mouse models, the expression of FGF-23 mRNA is significantly increased in bone cells, resulting in reduced bone mineralization [163]. Additionally, it has been reported that FGF-23 expression can be regulated by inflammation and iron deficiency. Induction of inflammation in mice using IL-1 $\beta$, LPS, and/or TNF correlates with increased expression levels of FGF-23 in osteocytes, both in humans and in mice [164], but also in CKD and inflammation in other organs [165]. David et al. showed that IL1 $\beta$-induced inflammation resulted in an FGF-23 increase, accompanied by a significant ferritin increase and a decrease of iron in the serum. Interestingly, the same study demonstrated that increased skeletal FGF-23 expression during inflammation remained even after the administration of the PHD inhibitor FG-4592 [166] (roxadustat-one of the PHD inhibitors currently in clinical trials for CKD treatment [167]). Conversely, another in vitro study in bone derived cell line showed increased FGF-23 mRNA expression upon HIF1 $\alpha$ activation [168]. Noonan et al. studied the role of the HIF/EPO/FGF-23 axis in iron metabolism in an early-stage CKD mouse model. They reported that, upon treatment with HIF-PHD inhibitor FG-4592, iFGF-23 serum levels dropped remarkably. As a result, the deficiency of iron metabolism stabilized through decreased liver ferritin, Bmp6, and hepcidin mRNAs [169]. Taken together, FGF-23 constitutes an important regulator of erythropoiesis and bone homeostasis. Although there is supporting evidence linking the regulatory role of HIFs and FGF-23 expression, additional studies are required to unravel the molecular mechanisms linked to these HPPs (Figure 2).

\section{Conclusions}

Taken together, hypoxia pathway proteins play direct and indirect roles during the complex process of erythropoiesis. Therefore, the multifaceted regulation of all these proteins is essential in order to preserve the enormous demand for red blood cells needed under steady-state but also stress situations. The most crucial member of this system is EPO, primarily produced in the kidney, and directly regulated by the PHD2/HIF2 $\alpha$ axis. Besides its impact on the development of red blood cells, EPO plays an essential role in iron metabolism by regulating hepcidin expression in the liver. In addition, EPO steers the production and processing of other growth factors (e.g., FGF-23) that are essential during erythropoiesis and, in that way, regulates its own production. Due to the essential roles of HPPs in erythropoiesis, the development of HIF stabilizers and PHD inhibitors as therapeutic agents are under detailed investigation for the treatment of anemias of various etiologies. However, more research is necessary to better understand the wide impact of the central HPPs, especially for the chronic intervention of this pathway.

Author Contributions: D.W., D.G., D.R., S.S. and B.W. wrote the manuscript; D.H. and M.R. contributed to the discussion and edited the manuscript. All authors have read and agreed to the published version of the manuscript. 
Funding: This work was supported by grants from the DFG (German Research Foundation) within the CRC/Transregio 205/1, Project No. 314061271-TRR205, "The Adrenal: Central Relay in Health and Disease" (A02) to B.W.; DFG grants WI3291/5-1 and 12-1 to B.W. and RA1923/12-1 to M.R. This work was supported by grants from the German-Israeli Foundation to M.R., and B.W. and the DFG priority program $\mu$ BONE 2084 to M.R. and B.W. B.W. was further supported by the DFG Heisenberg program (WI3291/13-1).

Conflicts of Interest: The authors have declared that no conflict of interest exists.

\section{References}

1. Oburoglu, L.; Romano, M.; Taylor, N.; Kinet, S. Metabolic regulation of hematopoietic stem cell commitment and erythroid differentiation. Curr. Opin. Hematol. 2016, 23, 198-205. [CrossRef] [PubMed]

2. Alnaeeli, M.; Wang, L.; Piknova, B.; Rogers, H.; Li, X.; Noguchi, C.T. Erythropoietin in brain development and beyond. Anat. Res. Int. 2012, 2012, 953264. [CrossRef] [PubMed]

3. Suresh, S.; Rajvanshi, P.K.; Noguchi, C.T. The Many Facets of Erythropoietin Physiologic and Metabolic Response. Front. Physiol. 2019, 10, 1534. [CrossRef] [PubMed]

4. Rankin, E.B.; Wu, C.; Khatri, R.; Wilson, T.L.; Andersen, R.; Araldi, E.; Rankin, A.L.; Yuan, J.; Kuo, C.J.; Schipani, E.; et al. The HIF signaling pathway in osteoblasts directly modulates erythropoiesis through the production of EPO. Cell 2012, 149, 63-74. [CrossRef]

5. Urrutia, A.A.; Afzal, A.; Nelson, J.; Davidoff, O.; Gross, K.W.; Haase, V.H. Prolyl-4-hydroxylase 2 and 3 coregulate murine erythropoietin in brain pericytes. Blood 2016, 128, 2550-2560. [CrossRef]

6. Nagai, A.; Nakagawa, E.; Choi, H.B.; Hatori, K.; Kobayashi, S.; Kim, S.U. Erythropoietin and Erythropoietin Receptors in Human CNS Neurons, Astrocytes, Microglia, and Oligodendrocytes Grown in Culture. J. Neuropathol. Exp. Neurol. 2001, 60, 386-392. [CrossRef]

7. Zivot, A.; Lipton, J.M.; Narla, A.; Blanc, L. Erythropoiesis: Insights into pathophysiology and treatments in 2017. Mol. Med. 2018, 24, 11. [CrossRef]

8. Suzuki, N.; Yamamoto, M. Roles of renal erythropoietin-producing (REP) cells in the maintenance of systemic oxygen homeostasis. Pflug. Arch. 2016, 468, 3-12. [CrossRef]

9. Semenza, G.L.; Wang, G.L. A nuclear factor induced by hypoxia via de novo protein synthesis binds to the human erythropoietin gene enhancer at a site required for transcriptional activation. Mol. Cell Biol. 1992, 12, 5447-5454. [CrossRef]

10. Lando, D.; Peet, D.J.; Gorman, J.J.; Whelan, D.A.; Whitelaw, M.L.; Bruick, R.K. FIH-1 is an asparaginyl hydroxylase enzyme that regulates the transcriptional activity of hypoxia-inducible factor. Genes Dev. 2002, 16, 1466-1471. [CrossRef]

11. Epstein, A.C.; Gleadle, J.M.; McNeill, L.A.; Hewitson, K.S.; O’Rourke, J.; Mole, D.R.; Mukherji, M.; Metzen, E.; Wilson, M.I.; Dhanda, A.; et al. C. elegans EGL-9 and mammalian homologs define a family of dioxygenases that regulate HIF by prolyl hydroxylation. Cell 2001, 107, 43-54. [CrossRef]

12. Ivan, M.; Kondo, K.; Yang, H.; Kim, W.; Valiando, J.; Ohh, M.; Salic, A.; Asara, J.M.; Lane, W.S.; Kaelin, W.G. HIFalpha targeted for VHL-mediated destruction by proline hydroxylation: Implications for O2 sensing. Science 2001, 292, 464-468. [CrossRef] [PubMed]

13. Hirano, I.; Suzuki, N.; Yamazaki, S.; Sekine, H.; Minegishi, N.; Shimizu, R.; Yamamoto, M. Renal Anemia Model Mouse Established by Transgenic Rescue with an Erythropoietin Gene Lacking Kidney-Specific Regulatory Elements. Mol. Cell Biol. 2017, 37. [CrossRef]

14. Meneses, A.M.; Wielockx, B. PHD2: From hypoxia regulation to disease progression. Hypoxia (Auckl) 2016, 4, 53-67. [CrossRef] [PubMed]

15. Sormendi, S.; Wielockx, B. Hypoxia Pathway Proteins As Central Mediators of Metabolism in the Tumor Cells and Their Microenvironment. Front. Immunol. 2018, 9, 40. [CrossRef]

16. Locatelli, F.; Fishbane, S.; Block, G.A.; Macdougall, I.C. Targeting Hypoxia-Inducible Factors for the Treatment of Anemia in Chronic Kidney Disease Patients. Am. J. Nephrol. 2017, 45, 187-199. [CrossRef]

17. Masson, N.; Willam, C.; Maxwell, P.H.; Pugh, C.W.; Ratcliffe, P.J. Independent function of two destruction domains in hypoxia-inducible factor-alpha chains activated by prolyl hydroxylation. EMBO J. 2001, 20, 5197-5206. [CrossRef]

18. Jaakkola, P.; Mole, D.R.; Tian, Y.M.; Wilson, M.I.; Gielbert, J.; Gaskell, S.J.; Av, K.; Hebestreit, H.F.; Mukherji, M.; Schofield, C.J.; et al. Targeting of HIF-alpha to the von Hippel-Lindau ubiquitylation complex by O2-regulated prolyl hydroxylation. Science 2001, 292, 468-472. [CrossRef] 
19. Bruick, R.K.; McKnight, S.L. A conserved family of prolyl-4-hydroxylases that modify HIF. Science 2001, 294, 1337-1340. [CrossRef]

20. Mahon, P.C.; Hirota, K.; Semenza, G.L. FIH-1: A novel protein that interacts with HIF-1alpha and VHL to mediate repression of HIF-1 transcriptional activity. Genes Dev. 2001, 15, 2675-2686. [CrossRef]

21. Cockman, M.E.; Lippl, K.; Tian, Y.M.; Pegg, H.B.; Figg, W.D.J.; Abboud, M.I.; Heilig, R.; Fischer, R.; Myllyharju, J.; Schofield, C.J.; et al. Lack of activity of recombinant HIF prolyl hydroxylases (PHDs) on reported non-HIF substrates. Elife 2019, 8. [CrossRef]

22. Appelhoff, R.J.; Tian, Y.-M.; Raval, R.R.; Turley, H.; Harris, A.L.; Pugh, C.W.; Ratcliffe, P.J.; Gleadle, J.M. Differential function of the prolyl hydroxylases PHD1, PHD2, and PHD3 in the regulation of hypoxia-inducible factor. J. Biol. Chem. 2004, 279, 38458-38465. [CrossRef] [PubMed]

23. Berra, E.; Benizri, E.; Ginouvès, A.; Volmat, V.; Roux, D.; Pouysségur, J. HIF prolyl-hydroxylase 2 is the key oxygen sensor setting low steady-state levels of HIF-1alpha in normoxia. EMBO J. 2003, 22, 4082-4090. [CrossRef] [PubMed]

24. Takeda, K.; Ho, V.C.; Takeda, H.; Duan, L.-J.J.; Nagy, A.; Fong, G.-H.H. Placental but not heart defects are associated with elevated hypoxia-inducible factor alpha levels in mice lacking prolyl hydroxylase domain protein 2. Mol. Cell Biol. 2006, 26, 8336-8346. [CrossRef] [PubMed]

25. Minamishima, Y.A.; Moslehi, J.; Bardeesy, N.; Cullen, D.; Bronson, R.T.; Kaelin, W.G. Somatic inactivation of the PHD2 prolyl hydroxylase causes polycythemia and congestive heart failure. Blood 2008, 111, 3236-3244. [CrossRef]

26. Aragones, J.; Schneider, M.; Van Geyte, K.; Fraisl, P.; Dresselaers, T.; Mazzone, M.; Dirkx, R.; Zacchigna, S.; Lemieux, H.; Jeoung, N.H.; et al. Deficiency or inhibition of oxygen sensor Phd1 induces hypoxia tolerance by reprogramming basal metabolism. Nat. Genet. 2008, 40, 170-180. [CrossRef]

27. Bishop, T.; Gallagher, D.; Pascual, A.; Lygate, C.A.; de Bono, J.P.; Nicholls, L.G.; Ortega-Saenz, P.; Oster, H.; Wijeyekoon, B.; Sutherland, A.I.; et al. Abnormal sympathoadrenal development and systemic hypotension in PHD3-/- mice. Mol. Cell Biol. 2008, 28, 3386-3400. [CrossRef]

28. Arsenault, P.R.; Song, D.; Chung, Y.J.; Khurana, T.S.; Lee, F.S. The Zinc Finger of Prolyl Hydroxylase Domain Protein 2 Is Essential for Efficient Hydroxylation of Hypoxia-Inducible Factor alpha. Mol. Cell Biol. 2016, 36, 2328-2343. [CrossRef]

29. Sinnema, M.; Song, D.; Guan, W.; Janssen, J.W.H.; van Wijk, R.; Navalsky, B.E.; Peng, K.; Donker, A.E.; Stegmann, A.P.A.; Lee, F.S. Loss-of-function zinc finger mutation in the EGLN1 gene associated with erythrocytosis. Blood 2018, 132, 1455-1458. [CrossRef]

30. Matsui-Hasumi, A.; Sato, Y.; Uto-Konomi, A.; Yamashita, S.; Uehori, J.; Yoshimura, A.; Yamashita, M.; Asahara, H.; Suzuki, S.; Kubo, M. E3 ubiquitin ligases SIAH1/2 regulate hypoxia-inducible factor-1 (HIF-1)-mediated Th17 cell differentiation. Int. Immunol. 2017, 29, 133-143. [CrossRef]

31. Niu, G.; Briggs, J.; Deng, J.; Ma, Y.; Lee, H.; Kortylewski, M.; Kujawski, M.; Kay, H.; Cress, W.D.; Jove, R.; et al. Signal Transducer and Activator of Transcription 3 Is Required for Hypoxia-Inducible Factor- $1 \alpha$ RNA Expression in Both Tumor Cells and Tumor-Associated Myeloid Cells. Mol. Cancer Res. 2008, 6, 1099. [CrossRef] [PubMed]

32. Bonello, S.; Zähringer, C.; BelAiba Rachida, S.; Djordjevic, T.; Hess, J.; Michiels, C.; Kietzmann, T.; Görlach, A. Reactive Oxygen Species Activate the HIF-1 $\alpha$ Promoter Via a Functional NFkB Site. Arterioscler. Thromb. Vasc. Biol. 2007, 27, 755-761. [CrossRef]

33. Dai, Z.; Li, M.; Wharton, J.; Zhu, M.M.; Zhao, Y.Y. Prolyl-4 Hydroxylase 2 (PHD2) Deficiency in Endothelial Cells and Hematopoietic Cells Induces Obliterative Vascular Remodeling and Severe Pulmonary Arterial Hypertension in Mice and Humans Through Hypoxia-Inducible Factor-2alpha. Circulation 2016, 133, 2447-2458. [CrossRef]

34. Franke, K.; Gassmann, M.; Wielockx, B. Erythrocytosis: The HIF pathway in control. Blood 2013, 122, 1122-1128. [CrossRef]

35. Wiesener, M.S.; Jürgensen, J.S.; Rosenberger, C.; Scholze, C.; Hörstrup, J.H.; Warnecke, C.; Mandriota, S.; Bechmann, I.; Frei, U.A.; Pugh, C.W.; et al. Widespread, hypoxia-inducible expression of HIF-2 $\alpha$ in distinct cell populations of different organs. FASEB J. 2003, 17, 271-273. [CrossRef] [PubMed] 
36. Korovina, I.; Neuwirth, A.; Sprott, D.; Weber, S.; Sardar Pasha, S.P.B.; Gercken, B.; Breier, G.; El-Armouche, A.; Deussen, A.; Karl, M.O.; et al. Hematopoietic hypoxia-inducible factor 2alpha deficiency ameliorates pathological retinal neovascularization via modulation of endothelial cell apoptosis. FASEB J. 2019, 33, 1758-1770. [CrossRef] [PubMed]

37. Garcia-Martin, R.; Alexaki, V.I.; Qin, N.; Rubin de Celis, M.F.; Economopoulou, M.; Ziogas, A.; Gercken, B.; Kotlabova, K.; Phieler, J.; Ehrhart-Bornstein, M.; et al. Adipocyte-Specific Hypoxia-Inducible Factor 2alpha Deficiency Exacerbates Obesity-Induced Brown Adipose Tissue Dysfunction and Metabolic Dysregulation. Mol. Cell Biol. 2016, 36, 376-393. [CrossRef]

38. Lee, K.E.; Simon, M.C. SnapShot: Hypoxia-Inducible Factors. Cell 2015, 163, 1288-1288.e1. [CrossRef] [PubMed]

39. Greenald, D.; Jeyakani, J.; Pelster, B.; Sealy, I.; Mathavan, S.; van Eeden, F.J. Genome-wide mapping of Hif-1 $\alpha$ binding sites in zebrafish. BMC Genom. 2015, 16, 923. [CrossRef]

40. Smythies, J.A.; Sun, M.; Masson, N.; Salama, R.; Simpson, P.D.; Murray, E.; Neumann, V.; Cockman, M.E.; Choudhry, H.; Ratcliffe, P.J.; et al. Inherent DNA-binding specificities of the HIF-1alpha and HIF-2alpha transcription factors in chromatin. EMBO Rep. 2019, 20. [CrossRef]

41. Cavadas, M.A.S.; Mesnieres, M.; Crifo, B.; Manresa, M.C.; Selfridge, A.C.; Keogh, C.E.; Fabian, Z.; Scholz, C.C.; Nolan, K.A.; Rocha, L.M.A.; et al. REST is a hypoxia-responsive transcriptional repressor. Sci. Rep. 2016, 6, 31355. [CrossRef]

42. Cavadas, M.; Cheong, A.; Taylor, C. The regulation of transcriptional repression in hypoxia. Exp. Cell Res. 2017, 356. [CrossRef]

43. Choudhry, H.; Harris, A.L. Advances in Hypoxia-Inducible Factor Biology. Cell Metab. 2018, 27, $281-298$. [CrossRef]

44. Watts, D.; Stein, J.; Meneses, A.; Bechmann, N.; Neuwirth, A.; Kaden, D.; Krüger, A.; Sinha, A.; Alexaki, V.I.; Perez-Rivas, L.G.; et al. HIF1 $\alpha$ is an essential regulator of steroidogenesis in the adrenal gland. bioRxiv 2020. [CrossRef]

45. Ivan, M.; Huang, X. miR-210: Fine-tuning the hypoxic response. Adv. Exp. Med. Biol. 2014, 772, $205-227$. [CrossRef]

46. Serocki, M.; Bartoszewska, S.; Janaszak-Jasiecka, A.; Ochocka, R.J.; Collawn, J.F.; Bartoszewski, R. miRNAs regulate the HIF switch during hypoxia: A novel therapeutic target. Angiogenesis 2018, 21, 183-202. [CrossRef]

47. Wang, X.; Li, J.; Wu, D.; Bu, X.; Qiao, Y. Hypoxia promotes apoptosis of neuronal cells through hypoxia-inducible factor-1 $\alpha$-microRNA-204-B-cell lymphoma-2 pathway. Exp. Biol. Med. (Maywood) 2016, 241, 177-183. [CrossRef] [PubMed]

48. Camps, C.; Saini, H.K.; Mole, D.R.; Choudhry, H.; Reczko, M.; Guerra-Assunção, J.A.; Tian, Y.-M.; Buffa, F.M.; Harris, A.L.; Hatzigeorgiou, A.G.; et al. Integrated analysis of microRNA and mRNA expression and association with HIF binding reveals the complexity of microRNA expression regulation under hypoxia. Mol. Cancer 2014, 13, 28. [CrossRef] [PubMed]

49. Poitz, D.M.; Augstein, A.; Gradehand, C.; Ende, G.; Schmeisser, A.; Strasser, R.H. Regulation of the Hif-system by micro-RNA 17 and 20a - role during monocyte-to-macrophage differentiation. Mol. Immunol. 2013, 56, 442-451. [CrossRef]

50. Umezu, T.; Tadokoro, H.; Azuma, K.; Yoshizawa, S.; Ohyashiki, K.; Ohyashiki, J.H. Exosomal miR-135b shed from hypoxic multiple myeloma cells enhances angiogenesis by targeting factor-inhibiting HIF-1. Blood 2014, 124, 3748-3757. [CrossRef]

51. Arsenault, P.R.; Pei, F.; Lee, R.; Kerestes, H.; Percy, M.J.; Keith, B.; Simon, M.C.; Lappin, T.R.; Khurana, T.S.; Lee, F.S. A knock-in mouse model of human PHD2 gene-associated erythrocytosis establishes a haploinsufficiency mechanism. J. Biol. Chem. 2013, 288, 33571-33584. [CrossRef] [PubMed]

52. Franke, K.; Kalucka, J.; Mamlouk, S.; Singh, R.P.; Muschter, A.; Weidemann, A.; Iyengar, V.; Jahn, S.; Wieczorek, K.; Geiger, K.; et al. HIF-1alpha is a protective factor in conditional PHD2-deficient mice suffering from severe HIF-2alpha-induced excessive erythropoiesis. Blood 2013, 121, 1436-1445. [CrossRef]

53. Ladroue, C.; Carcenac, R.; Leporrier, M.; Gad, S.; Hello, C.L.; Galateau-Salle, F.; Feunteun, J.; Pouysségur, J.; Richard, S.; Gardie, B. PHD2 mutation and congenital erythrocytosis with paraganglioma. N. Engl. J. Med. 2008, 359, 2685-2692. [CrossRef] [PubMed] 
54. Al-Sheikh, M.; Moradkhani, K.; Lopez, M.; Wajcman, H.; Préhu, C. Disturbance in the HIF-1alpha pathway associated with erythrocytosis: Further evidences brought by frameshift and nonsense mutations in the prolyl hydroxylase domain protein 2 (PHD2) gene. Blood Cells Mol. Dis. 2008, 40, 160-165. [CrossRef] [PubMed]

55. Gardie, B.; Percy, M.J.; Hoogewijs, D.; Chowdhury, R.; Bento, C.; Arsenault, P.R.; Richard, S.; Almeida, H.; Ewing, J.; Lambert, F.; et al. The role of PHD2 mutations in the pathogenesis of erythrocytosis. Hypoxia (Auckl.) 2014, 2, 71-90. [CrossRef] [PubMed]

56. Forsythe, J.A.; Jiang, B.H.; Iyer, N.V.; Agani, F.; Leung, S.W.; Koos, R.D.; Semenza, G.L. Activation of vascular endothelial growth factor gene transcription by hypoxia-inducible factor 1. Mol. Cell Biol. 1996, 16, 4604-4613. [CrossRef]

57. Maxwell, P.H.; Pugh, C.W.; Ratcliffe, P.J. Inducible operation of the erythropoietin 3' enhancer in multiple cell lines: Evidence for a widespread oxygen-sensing mechanism. Proc. Natl. Acad. Sci. USA 1993, 90, $2423-2427$. [CrossRef]

58. Wang, G.L.; Jiang, B.H.; Rue, E.A.; Semenza, G.L. Hypoxia-inducible factor 1 is a basic-helix-loop-helix-PAS heterodimer regulated by cellular O2 tension. Proc. Natl. Acad. Sci. USA 1995, 92, 5510-5514. [CrossRef]

59. Tacchini, L.; Bianchi, L.; Bernelli-Zazzera, A.; Cairo, G. Transferrin receptor induction by hypoxia. HIF-1-mediated transcriptional activation and cell-specific post-transcriptional regulation. J. Biol. Chem. 1999, 274, 24142-24146. [CrossRef]

60. Lok, C.N.; Ponka, P. Identification of a hypoxia response element in the transferrin receptor gene. J. Biol. Chem. 1999, 274, 24147-24152. [CrossRef]

61. Rolfs, A.; Kvietikova, I.; Gassmann, M.; Wenger, R.H. Oxygen-regulated transferrin expression is mediated by hypoxia-inducible factor-1. J. Biol. Chem. 1997, 272, 20055-20062. [CrossRef] [PubMed]

62. Zhang, F.L.; Shen, G.M.; Liu, X.L.; Wang, F.; Zhao, Y.Z.; Zhang, J.W. Hypoxia-inducible factor 1-mediated human GATA1 induction promotes erythroid differentiation under hypoxic conditions. J. Cell Mol. Med. 2012, 16, 1889-1899. [CrossRef] [PubMed]

63. Katsumura, K.R.; Bresnick, E.H.; Group, G.F.M. The GATA factor revolution in hematology. Blood 2017, 129, 2092-2102. [CrossRef]

64. Palis, J. Primitive and definitive erythropoiesis in mammals. Front. Physiol. 2014, 5. [CrossRef] [PubMed]

65. Xie, Y.; Li, W.; Feng, J.; Wu, T.; Li, J. MicroRNA-363 and GATA-1 are regulated by HIF-1alpha in K562 cells under hypoxia. Mol. Med. Rep. 2016, 14, 2503-2510. [CrossRef] [PubMed]

66. Percy, M.J.; Furlow, P.W.; Lucas, G.S.; Li, X.; Lappin, T.R.J.; McMullin, M.F.; Lee, F.S. A gain-of-function mutation in the HIF2A gene in familial erythrocytosis. New Engl. J. Med. 2008, 358, 162-168. [CrossRef] [PubMed]

67. Pang, Y.; Gupta, G.; Jha, A.; Yue, X.; Wang, H.; Huynh, T.T.; Li, A.; Li, L.; Baker, E.; Chew, E.; et al. Nonmosaic somatic HIF2A mutations associated with late onset polycythemia-paraganglioma syndrome: Newly recognized subclass of polycythemia-paraganglioma syndrome. Cancer 2019, 125, 1258-1266. [CrossRef]

68. Wang, H.; Cui, J.; Yang, C.; Rosenblum, J.S.; Zhang, Q.; Song, Q.; Pang, Y.; Fang, F.; Sun, M.; Dmitriev, P.; et al. A Transgenic Mouse Model of Pacak(-)Zhuang Syndrome with An Epas1 Gain-of-Function Mutation. Cancers 2019, 11, 667. [CrossRef]

69. Su, T.; Liu, P.; Ti, X.; Wu, S.; Xue, X.; Wang, Z.; Dioum, E.; Zhang, Q. HIF1alpha, EGR1 and SP1 co-regulate the erythropoietin receptor expression under hypoxia: An essential role in the growth of non-small cell lung cancer cells. Cell Commun Signal. 2019, 17, 152. [CrossRef]

70. Ostrowski, D.; Heinrich, R. Alternative Erythropoietin Receptors in the Nervous System. J. Clin. Med. 2018, 7, 24. [CrossRef]

71. Soliz, J.; Gassmann, M.; Joseph, V. Soluble erythropoietin receptor is present in the mouse brain and is required for the ventilatory acclimatization to hypoxia. J. Physiol. 2007, 583, 329-336. [CrossRef] [PubMed]

72. Liu, Y.; Pop, R.; Sadegh, C.; Brugnara, C.; Haase, V.H.; Socolovsky, M. Suppression of Fas-FasL coexpression by erythropoietin mediates erythroblast expansion during the erythropoietic stress response in vivo. Blood 2006, 108, 123-133. [CrossRef]

73. Mastrogiannaki, M.; Matak, P.; Mathieu, J.R.R.; Delga, S.; Mayeux, P.; Vaulont, S.; Peyssonnaux, C. Hepatic hypoxia-inducible factor-2 down-regulates hepcidin expression in mice through an erythropoietin-mediated increase in erythropoiesis. Haematologica 2012, 97, 827-834. [CrossRef] [PubMed] 
74. Sonnweber, T.; Nachbaur, D.; Schroll, A.; Nairz, M.; Seifert, M.; Demetz, E.; Haschka, D.; Mitterstiller, A.-M.; Kleinsasser, A.; Burtscher, M.; et al. Hypoxia induced downregulation of hepcidin is mediated by platelet derived growth factor BB. Gut 2014, 63, 1951. [CrossRef]

75. Schwartz, A.J.; Das, N.K.; Ramakrishnan, S.K.; Jain, C.; Jurkovic, M.T.; Wu, J.; Nemeth, E.; Lakhal-Littleton, S.; Colacino, J.A.; Shah, Y.M. Hepatic hepcidin/intestinal HIF-2alpha axis maintains iron absorption during iron deficiency and overload. J. Clin. Invest. 2019, 129, 336-348. [CrossRef] [PubMed]

76. Gammella, E.; Diaz, V.; Recalcati, S.; Buratti, P.; Samaja, M.; Dey, S.; Noguchi, C.T.; Gassmann, M.; Cairo, G. Erythropoietin's inhibiting impact on hepcidin expression occurs indirectly. Am. J. Physiol. Regul. Integr. Comp. Physiol. 2015, 308, R330-R335. [CrossRef]

77. Camaschella, C.; Nai, A.; Silvestri, L. Iron metabolism and iron disorders revisited in the hepcidin era. Haematologica 2020, 105, 260-272. [CrossRef]

78. Taylor, M.; Qu, A.; Anderson, E.R.; Matsubara, T.; Martin, A.; Gonzalez, F.J.; Shah, Y.M. Hypoxia-inducible factor- $2 \alpha$ mediates the adaptive increase of intestinal ferroportin during iron deficiency in mice. Gastroenterology 2011, 140, 2044-2055. [CrossRef]

79. Arezes, J.; Foy, N.; McHugh, K.; Sawant, A.; Quinkert, D.; Terraube, V.; Brinth, A.; Tam, M.; LaVallie, E.R.; Taylor, S.; et al. Erythroferrone inhibits the induction of hepcidin by BMP6. Blood 2018, 132, 1473-1477. [CrossRef]

80. Kautz, L.; Jung, G.; Valore, E.V.; Rivella, S.; Nemeth, E.; Ganz, T. Identification of erythroferrone as an erythroid regulator of iron metabolism. Nat. Genet. 2014, 46, 678-684. [CrossRef]

81. van Vuren, A.J.; Gaillard, C.; Eisenga, M.F.; van Wijk, R.; van Beers, E.J. The EPO-FGF-23 Signaling Pathway in Erythroid Progenitor Cells: Opening a New Area of Research. Front. Physiol. 2019, 10, 304. [CrossRef]

82. Daryadel, A.; Bettoni, C.; Haider, T.; Imenez Silva, P.H.; Schnitzbauer, U.; Pastor-Arroyo, E.M.; Wenger, R.H.; Gassmann, M.; Wagner, C.A. Erythropoietin stimulates fibroblast growth factor 23 (FGF-23) in mice and men. Pflug. Arch. 2018, 470, 1569-1582. [CrossRef] [PubMed]

83. Hanudel, M.; Eisenga, M.; Rappaport, M.; Chua, K.J.; Qiao, B.; Jung, C.-L.; Gabayan, V.; Gales, B.; Ramos, G.; Jong, M.; et al. Effects of erythropoietin on fibroblast growth factor 23 in mice and humans. Nephrol. Dial. Transplant. Off. Publ. Eur. Dial. Transpl. Assoc. Eur. Ren. Assoc. 2018, 34. [CrossRef] [PubMed]

84. Kuhrt, D.; Wojchowski, D.M. Emerging EPO and EPO receptor regulators and signal transducers. Blood 2015, 125, 3536-3541. [CrossRef] [PubMed]

85. Chow, A.; Huggins, M.; Ahmed, J.; Hashimoto, D.; Lucas, D.; Kunisaki, Y.; Pinho, S.; Leboeuf, M.; Noizat, C.; van Rooijen, N.; et al. CD169(+) macrophages provide a niche promoting erythropoiesis under homeostasis and stress. Nat. Med. 2013, 19, 429-436. [CrossRef]

86. Ramos, P.; Casu, C.; Gardenghi, S.; Breda, L.; Crielaard, B.J.; Guy, E.; Marongiu, M.F.; Gupta, R.; Levine, R.L.; Abdel-Wahab, O.; et al. Macrophages support pathological erythropoiesis in polycythemia vera and beta-thalassemia. Nat. Med. 2013, 19, 437-445. [CrossRef] [PubMed]

87. An, X.; Schulz, V.P.; Mohandas, N.; Gallagher, P.G. Human and murine erythropoiesis. Curr. Opin. Hematol. 2015, 22, 206-211. [CrossRef]

88. Simon, M.C. Transcription factor GATA-1 and erythroid development. Proc. Soc. Exp. Biol. Med. 1993, 202, 115-121. [CrossRef]

89. Cantor, A.B.; Orkin, S.H. Transcriptional regulation of erythropoiesis: An affair involving multiple partners. Oncogene 2002, 21, 3368-3376. [CrossRef]

90. Ribeil, J.-A.; Zermati, Y.; Vandekerckhove, J.; Cathelin, S.; Kersual, J.; Dussiot, M.; Coulon, S.; Moura, I.C.; Zeuner, A.; Kirkegaard-Sørensen, T.; et al. Hsp70 regulates erythropoiesis by preventing caspase-3-mediated cleavage of GATA-1. Nat. Cell Biol. 2006, 445, 102-105. [CrossRef]

91. Valent, P.; Busche, G.; Theurl, I.; Uras, I.Z.; Germing, U.; Stauder, R.; Sotlar, K.; Fureder, W.; Bettelheim, P.; Pfeilstocker, M.; et al. Normal and pathological erythropoiesis in adults: From gene regulation to targeted treatment concepts. Haematologica 2018, 103, 1593-1603. [CrossRef] [PubMed]

92. Kim, S.I.; Bresnick, E.H. Transcriptional control of erythropoiesis: Emerging mechanisms and principles. Oncogene 2007, 26, 6777-6794. [CrossRef] [PubMed]

93. Gregory, T.; Yu, C.; Ma, A.; Orkin, S.H.; Blobel, G.A.; Weiss, M.J. GATA-1 and Erythropoietin Cooperate to Promote Erythroid Cell Survival by Regulating bcl-xL Expression. Blood 1999, 94, 87-96. [CrossRef] 
94. Zon, L.I.; Youssoufian, H.; Mather, C.; Lodish, H.F.; Orkin, S.H. Activation of the erythropoietin receptor promoter by transcription factor GATA-1. Proc. Natl. Acad. Sci. USA 1991, 88, 10638-10641. [CrossRef] [PubMed]

95. Liu, F.; Wei, W.; Ding, J.; Chen, Y.; Feng, T.T.; Ji, L.H.; Shi, J.Y. Influence of HIF- $2 \alpha$ on the expression of GATA1 in bone marrow CD71(+) cell of high altitude polycythemia rat model. Zhonghua Xue Ye Xue Za Zhi= Zhonghua Xueyexue Zazhi 2016, 37, 696-701. [CrossRef] [PubMed]

96. Johnson, K.D.; Kong, G.; Gao, X.; Chang, Y.-I.; Hewitt, K.J.; Sanalkumar, R.; Prathibha, R.; Ranheim, E.A.; Dewey, C.N.; Zhang, J.; et al. Cis-regulatory mechanisms governing stem and progenitor cell transitions. Sci. Adv. 2015, 1, e1500503. [CrossRef]

97. Zhang, L.; Flygare, J.; Wong, P.; Lim, B.; Lodish, H.F. miR-191 regulates mouse erythroblast enucleation by down-regulating Riok3 and Mxi1. Genes Dev. 2011, 25, 119-124. [CrossRef] [PubMed]

98. Bianchi, N.; Zuccato, C.; Lampronti, I.; Borgatti, M.; Gambari, R. Expression of miR-210 during erythroid differentiation and induction of gamma-globin gene expression. BMB Rep. 2009, 42, 493-499. [CrossRef]

99. Kim, M.; Tan, Y.S.; Cheng, W.C.; Kingsbury, T.J.; Heimfeld, S.; Civin, C.I. MIR144 and MIR451 regulate human erythropoiesis via RAB14. Br. J. Haematol. 2015, 168, 583-597. [CrossRef]

100. Rivkin, N.; Chapnik, E.; Mildner, A.; Barshtein, G.; Porat, Z.; Kartvelishvily, E.; Dadosh, T.; Birger, Y.; Amir, G.; Yedgar, S.; et al. Erythrocyte survival is controlled by microRNA-142. Haematologica 2017, 102, 676. [CrossRef]

101. Lu, Y.; Ji, N.; Wei, W.; Sun, W.; Gong, X.; Wang, X. MiR-142 modulates human pancreatic cancer proliferation and invasion by targeting hypoxia-inducible factor 1 (HIF-1alpha) in the tumor microenvironments. Biol. Open 2017, 6, 252-259. [CrossRef] [PubMed]

102. Yang, Y.; Ma, W.; Wu, D.; Huang, Y.; Li, H.; Zou, J.; Zhang, Y.; Feng, M.; Luo, J. MiR-17 Partly Promotes Hematopoietic Cell Expansion through Augmenting HIF-1 $\alpha$ in Osteoblasts. PLoS ONE 2013, 8, e70232. [CrossRef]

103. Sun, L.; Fan, F.; Li, R.; Niu, B.; Zhu, L.; Yu, S.; Wang, S.; Li, C.; Wang, D. Different Erythrocyte MicroRNA Profiles in Low- and High-Altitude Individuals. Front. Physiol. 2018, 9. [CrossRef]

104. Elliott, S.; Sinclair, A.M. The effect of erythropoietin on normal and neoplastic cells. Biologics 2012, 6, 163-189. [CrossRef] [PubMed]

105. Jelkmann, W. Erythropoietin. Front. Horm Res. 2016, 47, 115-127. [CrossRef]

106. Gouilleux, F.; Pallard, C.; Dusanter-Fourt, I.; Wakao, H.; Haldosen, L.A.; Norstedt, G.; Levy, D.; Groner, B. Prolactin, growth hormone, erythropoietin and granulocyte-macrophage colony stimulating factor induce MGF-Stat5 DNA binding activity. EMBO J. 1995, 14, 2005-2013. [CrossRef] [PubMed]

107. Koury, M.J.; Haase, V.H. Anaemia in kidney disease: Harnessing hypoxia responses for therapy. Nat. Rev. Nephrol. 2015, 11, 394-410. [CrossRef]

108. Obara, N.; Suzuki, N.; Kim, K.; Nagasawa, T.; Imagawa, S.; Yamamoto, M. Repression via the GATA box is essential for tissue-specific erythropoietin gene expression. Blood 2008, 111, 5223-5232. [CrossRef]

109. Broxmeyer, H.E. Erythropoietin: Multiple targets, actions, and modifying influences for biological and clinical consideration. J. Exp. Med. 2013, 210, 205-208. [CrossRef]

110. Suzuki, N.; Obara, N.; Pan, X.; Watanabe, M.; Jishage, K.; Minegishi, N.; Yamamoto, M. Specific contribution of the erythropoietin gene 3 ' enhancer to hepatic erythropoiesis after late embryonic stages. Mol. Cell Biol. 2011, 31, 3896-3905. [CrossRef]

111. Minamishima, Y.A.; Kaelin, W.G. Reactivation of hepatic EPO synthesis in mice after PHD loss. Science 2010, 329, 407. [CrossRef]

112. Mathia, S.; Paliege, A.; Koesters, R.; Peters, H.; Neumayer, H.H.; Bachmann, S.; Rosenberger, C. Action of hypoxia-inducible factor in liver and kidney from mice with Pax8-rtTA-based deletion of von Hippel-Lindau protein. Acta Physiol. (Oxf) 2013, 207, 565-576. [CrossRef] [PubMed]

113. Haase, V.H. HIF-prolyl hydroxylases as therapeutic targets in erythropoiesis and iron metabolism. Hemodial. Int. 2017, 21 (Suppl. 1), S110-S124. [CrossRef]

114. Farsijani, N.M.; Liu, Q.; Kobayashi, H.; Davidoff, O.; Sha, F.; Fandrey, J.; Ikizler, T.A.; O'Connor, P.M.; Haase, V.H. Renal epithelium regulates erythropoiesis via HIF-dependent suppression of erythropoietin. J. Clin. Investig. 2016, 126, 1425-1437. [CrossRef] [PubMed]

115. Tolonen, J.P.; Heikkila, M.; Malinen, M.; Lee, H.M.; Palvimo, J.J.; Wei, G.H.; Myllyharju, J. A long hypoxia-inducible factor 3 isoform 2 is a transcription activator that regulates erythropoietin. Cell Mol. Life Sci. 2019. [CrossRef] 
116. Heikkilä, M.; Pasanen, A.; Kivirikko, K.; Myllyharju, J. Roles of the human hypoxia-inducible factor (HIF)-3 $\alpha$ variants in the hypoxia response. Cell. Mol. Life Sci. Cmls 2011, 68, 3885-3901. [CrossRef]

117. Duan, C. Hypoxia-inducible factor 3 biology: Complexities and emerging themes. Am. J. Physiol. Cell Physiol. 2016, 310, C260-C269. [CrossRef]

118. Zhang, P.; Bai, Y.; Lu, L.; Li, Y.; Duan, C. An oxygen-insensitive Hif-3alpha isoform inhibits Wnt signaling by destabilizing the nuclear beta-catenin complex. Elife 2016, 5. [CrossRef]

119. Blanchard, K.L.; Acquaviva, A.M.; Galson, D.L.; Bunn, H.F. Hypoxic induction of the human erythropoietin gene: Cooperation between the promoter and enhancer, each of which contains steroid receptor response elements. Mol. Cell Biol. 1992, 12, 5373-5385. [CrossRef]

120. Haase, V.H. Regulation of erythropoiesis by hypoxia-inducible factors. Blood Rev. 2013, 27, 41-53. [CrossRef]

121. Storti, F.; Santambrogio, S.; Crowther, L.M.; Otto, T.; Abreu-Rodriguez, I.; Kaufmann, M.; Hu, C.J.; Dame, C.; Fandrey, J.; Wenger, R.H.; et al. A novel distal upstream hypoxia response element regulating oxygen-dependent erythropoietin gene expression. Haematologica 2014, 99, e45-e48. [CrossRef] [PubMed]

122. Schorg, A.; Santambrogio, S.; Platt, J.L.; Schodel, J.; Lindenmeyer, M.T.; Cohen, C.D.; Schrodter, K.; Mole, D.R.; Wenger, R.H.; Hoogewijs, D. Destruction of a distal hypoxia response element abolishes trans-activation of the PAG1 gene mediated by HIF-independent chromatin looping. Nucleic Acids Res. 2015, 43, 5810-5823. [CrossRef] [PubMed]

123. Platt, J.L.; Salama, R.; Smythies, J.; Choudhry, H.; Davies, J.O.; Hughes, J.R.; Ratcliffe, P.J.; Mole, D.R. Capture-C reveals preformed chromatin interactions between HIF-binding sites and distant promoters. EMBO Rep. 2016, 17, 1410-1421. [CrossRef]

124. Orlando, I.M.C.; Lafleur, V.N.; Storti, F.; Spielmann, P.; Crowther, L.; Santambrogio, S.; Schodel, J.; Hoogewijs, D.; Mole, D.R.; Wenger, R.H. Distal and proximal hypoxia response elements cooperate to regulate organ-specific erythropoietin gene expression. Haematologica 2019. [CrossRef] [PubMed]

125. Ji, P. Pericytes: New EPO-producing cells in the brain. Blood 2016, 128, 2483-2485. [CrossRef]

126. Pathipati, P.; Ferriero, D.M. The Differential Effects of Erythropoietin Exposure to Oxidative Stress on Microglia and Astrocytes in vitro. Dev. Neurosci. 2017, 39, 310-322. [CrossRef]

127. Hartmann, D.A.; Underly, R.G.; Grant, R.I.; Watson, A.N.; Lindner, V.; Shih, A.Y. Pericyte structure and distribution in the cerebral cortex revealed by high-resolution imaging of transgenic mice. Neurophotonics 2015, 2, 041402. [CrossRef]

128. Kobayashi, H.; Liu, Q.; Binns, T.C.; Urrutia, A.A.; Davidoff, O.; Kapitsinou, P.P.; Pfaff, A.S.; Olauson, H.; Wernerson, A.; Fogo, A.B.; et al. Distinct subpopulations of FOXD1 stroma-derived cells regulate renal erythropoietin. J. Clin. Invest. 2016, 126, 1926-1938. [CrossRef]

129. Acs, G.; Acs, P.; Beckwith, S.M.; Pitts, R.L.; Clements, E.; Wong, K.; Verma, A. Erythropoietin and erythropoietin receptor expression in human cancer. Cancer Res. 2001, 61, 3561-3565.

130. Vocanec, D.; Prijatelj, T.; Debeljak, N.; Kunej, T. Genetic variants of erythropoietin (EPO) and EPO receptor genes in familial erythrocytosis. Int. J. Lab. Hematol. 2019, 41, 162-167. [CrossRef]

131. Rundqvist, H.; Rullman, E.; Sundberg, C.J.; Fischer, H.; Eisleitner, K.; Stahlberg, M.; Sundblad, P.; Jansson, E.; Gustafsson, T. Activation of the erythropoietin receptor in human skeletal muscle. Eur. J. Endocrinol. 2009, 161, 427-434. [CrossRef] [PubMed]

132. Ogilvie, M.; Yu, X.; Nicolas-Metral, V.; Pulido, S.M.; Liu, C.; Ruegg, U.T.; Noguchi, C.T. Erythropoietin stimulates proliferation and interferes with differentiation of myoblasts. J. Biol. Chem. 2000, 275, 39754-39761. [CrossRef] [PubMed]

133. Liu, C.; Shen, K.; Liu, Z.; Noguchi, C.T. Regulated human erythropoietin receptor expression in mouse brain. J. Biol. Chem. 1997, 272, 32395-32400. [CrossRef] [PubMed]

134. Chepelev, N.L.; Willmore, W.G. Regulation of iron pathways in response to hypoxia. Free Radic Biol. Med. 2011, 50, 645-666. [CrossRef]

135. Shah, Y.M.; Matsubara, T.; Ito, S.; Yim, S.-H.; Gonzalez, F.J. Intestinal hypoxia-inducible transcription factors are essential for iron absorption following iron deficiency. Cell Metab. 2009, 9, 152-164. [CrossRef]

136. Mastrogiannaki, M.; Matak, P.; Delga, S.; Deschemin, J.C.; Vaulont, S.; Peyssonnaux, C. Deletion of HIF-2alpha in the enterocytes decreases the severity of tissue iron loading in hepcidin knockout mice. Blood 2012, 119, 587-590. [CrossRef]

137. Coffey, R.; Ganz, T. Iron homeostasis: An anthropocentric perspective. J. Biol. Chem. 2017, 292, 12727-12734. [CrossRef] 
138. Kim, A.; Nemeth, E. New insights into iron regulation and erythropoiesis. Curr. Opin. Hematol. 2015, 22, 199-205. [CrossRef]

139. Drakesmith, H.; Nemeth, E.; Ganz, T. Ironing out Ferroportin. Cell Metab. 2015, 22, 777-787. [CrossRef]

140. Coffey, R.; Ganz, T. Erythroferrone: An Erythroid Regulator of Hepcidin and Iron Metabolism. Hemasphere 2018, 2, e35. [CrossRef]

141. Pagani, A.; Nai, A.; Silvestri, L.; Camaschella, C. Hepcidin and Anemia: A Tight Relationship. Front. Physiol. 2019, 10, 1294. [CrossRef]

142. Nicolas, G.; Chauvet, C.; Viatte, L.; Danan, J.L.; Bigard, X.; Devaux, I.; Beaumont, C.; Kahn, A.; Vaulont, S. The gene encoding the iron regulatory peptide hepcidin is regulated by anemia, hypoxia, and inflammation. J. Clin. Invest. 2002, 110, 1037-1044. [CrossRef]

143. Peyssonnaux, C.; Zinkernagel, A.S.; Schuepbach, R.A.; Rankin, E.; Vaulont, S.; Haase, V.H.; Nizet, V.; Johnson, R.S. Regulation of iron homeostasis by the hypoxia-inducible transcription factors (HIFs). J. Clin. Investig. 2007, 117, 1926-1932. [CrossRef] [PubMed]

144. Suzuki, N.; Matsuo-Tezuka, Y.; Sasaki, Y.; Sato, K.; Miyauchi, K.; Kato, K.; Saito, S.; Shimonaka, Y.; Hirata, M.; Yamamoto, M. Iron attenuates erythropoietin production by decreasing hypoxia-inducible transcription factor 2alpha concentrations in renal interstitial fibroblasts. Kidney Int. 2018, 94, 900-911. [CrossRef] [PubMed]

145. Wilkinson, N.; Pantopoulos, K. IRP1 regulates erythropoiesis and systemic iron homeostasis by controlling HIF2 $\alpha$ mRNA translation. Blood 2013, 122, 1658-1668. [CrossRef]

146. Renassia, C.; Peyssonnaux, C. New insights into the links between hypoxia and iron homeostasis. Curr. Opin. Hematol. 2019, 26, 125-130. [CrossRef]

147. Lee, F.S. At the crossroads of oxygen and iron sensing: Hepcidin control of HIF-2alpha. J. Clin. Investig. 2019, 129, 72-74. [CrossRef]

148. Chen, T.K.; Knicely, D.H.; Grams, M.E. Chronic Kidney Disease Diagnosis and Management: A Review. JAMA 2019, 322, 1294-1304. [CrossRef]

149. Hasegawa, S.; Tanaka, T.; Nangaku, M. Hypoxia-inducible factor stabilizers for treating anemia of chronic kidney disease. Curr. Opin. Nephrol. Hypertens 2018, 27, 331-338. [CrossRef]

150. Shu, S.; Wang, Y.; Zheng, M.; Liu, Z.; Cai, J.; Tang, C.; Dong, Z. Hypoxia and Hypoxia-Inducible Factors in Kidney Injury and Repair. Cells 2019, 8, 207. [CrossRef]

151. Joharapurkar, A.A.; Pandya, V.B.; Patel, V.J.; Desai, R.C.; Jain, M.R. Prolyl Hydroxylase Inhibitors: A Breakthrough in the Therapy of Anemia Associated with Chronic Diseases. J. Med. Chem. 2018, 61, 6964-6982. [CrossRef] [PubMed]

152. Semenza, G.L. Pharmacologic Targeting of Hypoxia-Inducible Factors. Annu. Rev. Pharm. Toxicol. 2019, 59, 379-403. [CrossRef] [PubMed]

153. Del Vecchio, L.; Locatelli, F. Investigational hypoxia-inducible factor prolyl hydroxylase inhibitors (HIF-PHI) for the treatment of anemia associated with chronic kidney disease. Expert Opin. Investig. Drugs 2018, 27, 613-621. [CrossRef] [PubMed]

154. Schodel, J.; Ratcliffe, P.J. Mechanisms of hypoxia signalling: New implications for nephrology. Nat. Rev. Nephrol. 2019, 15, 641-659. [CrossRef]

155. Li, Z.L.; Tu, Y.; Liu, B.C. Treatment of Renal Anemia with Roxadustat: Advantages and Achievement. Kidney Dis. (Basel) 2020, 6, 65-73. [CrossRef]

156. Kaplan, J. Roxadustat and Anemia of Chronic Kidney Disease. N. Engl. J. Med. 2019, 381, 1070-1072. [CrossRef]

157. Anker, M.S.; Butler, J.; Anker, S.D. Roxadustat for Anemia in Patients with Chronic Kidney Disease. N. Engl. J. Med. 2020, 383, e3. [CrossRef]

158. Clinkenbeard, E.L.; Cass, T.A.; Ni, P.; Hum, J.M.; Bellido, T.; Allen, M.R.; White, K.E. Conditional Deletion of Murine Fgf23: Interruption of the Normal Skeletal Responses to Phosphate Challenge and Rescue of Genetic Hypophosphatemia. J. Bone Min. Res. 2016, 31, 1247-1257. [CrossRef]

159. Weidner, H.; Baschant, U.; Lademann, F.; Ledesma Colunga, M.G.; Balaian, E.; Hofbauer, C.; Misof, B.M.; Roschger, P.; Blouin, S.; Richards, W.G.; et al. Increased FGF-23 levels are linked to ineffective erythropoiesis and impaired bone mineralization in myelodysplastic syndromes. JCI Insight 2020, 5. [CrossRef]

160. Wolf, M.; White, K.E. Coupling fibroblast growth factor 23 production and cleavage: Iron deficiency, rickets, and kidney disease. Curr. Opin. Nephrol. Hypertens 2014, 23, 411-419. [CrossRef] 
161. Clinkenbeard, E.L.; Hanudel, M.R.; Stayrook, K.R.; Appaiah, H.N.; Farrow, E.G.; Cass, T.A.; Summers, L.J.; Ip, C.S.; Hum, J.M.; Thomas, J.C.; et al. Erythropoietin stimulates murine and human fibroblast growth factor-23, revealing novel roles for bone and bone marrow. Haematologica 2017, 102, e427-e430. [CrossRef] [PubMed]

162. Bar, L.; Stournaras, C.; Lang, F.; Foller, M. Regulation of fibroblast growth factor 23 (FGF-23) in health and disease. FEBS Lett. 2019, 593, 1879-1900. [CrossRef] [PubMed]

163. Andrukhova, O.; Schuler, C.; Bergow, C.; Petric, A.; Erben, R.G. Augmented Fibroblast Growth Factor-23 Secretion in Bone Locally Contributes to Impaired Bone Mineralization in Chronic Kidney Disease in Mice. Front. Endocrinol. (Lausanne) 2018, 9, 311. [CrossRef] [PubMed]

164. Ito, N.; Wijenayaka, A.R.; Prideaux, M.; Kogawa, M.; Ormsby, R.T.; Evdokiou, A.; Bonewald, L.F.; Findlay, D.M.; Atkins, G.J. Regulation of FGF-23 expression in IDG-SW3 osteocytes and human bone by pro-inflammatory stimuli. Mol. Cell Endocrinol. 2015, 399, 208-218. [CrossRef]

165. Egli-Spichtig, D.; Imenez Silva, P.H.; Glaudemans, B.; Gehring, N.; Bettoni, C.; Zhang, M.Y.H.; Pastor-Arroyo, E.M.; Schonenberger, D.; Rajski, M.; Hoogewijs, D.; et al. Tumor necrosis factor stimulates fibroblast growth factor 23 levels in chronic kidney disease and non-renal inflammation. Kidney Int. 2019, 96, 890-905. [CrossRef]

166. David, V.; Martin, A.; Isakova, T.; Spaulding, C.; Qi, L.; Ramirez, V.; Zumbrennen-Bullough, K.B.; Sun, C.C.; Lin, H.Y.; Babitt, J.L.; et al. Inflammation and functional iron deficiency regulate fibroblast growth factor 23 production. Kidney Int. 2016, 89, 135-146. [CrossRef]

167. Liu, J.; Zhang, A.; Hayden, J.C.; Bhagavathula, A.S.; Alshehhi, F.; Rinaldi, G.; Kontogiannis, V.; Rahmani, J. Roxadustat (FG-4592) treatment for anemia in dialysis-dependent (DD) and not dialysis-dependent (NDD) chronic kidney disease patients: A systematic review and meta-analysis. Pharm. Res. 2020, 155, 104747. [CrossRef]

168. Farrow, E.G.; Yu, X.; Summers, L.J.; Davis, S.I.; Fleet, J.C.; Allen, M.R.; Robling, A.G.; Stayrook, K.R.; Jideonwo, V.; Magers, M.J.; et al. Iron deficiency drives an autosomal dominant hypophosphatemic rickets (ADHR) phenotype in fibroblast growth factor-23 (Fgf23) knock-in mice. Proc. Natl. Acad. Sci. USA 2011, 108, E1146-L1155. [CrossRef]

169. Noonan, M.L.; Clinkenbeard, E.L.; Ni, P.; Swallow, E.A.; Tippen, S.P.; Agoro, R.; Allen, M.R.; White, K.E. Erythropoietin and a hypoxia-inducible factor prolyl hydroxylase inhibitor (HIF-PHDi) lowers FGF-23 in a model of chronic kidney disease (CKD). Physiol Rep. 2020, 8, e14434. [CrossRef]

Publisher's Note: MDPI stays neutral with regard to jurisdictional claims in published maps and institutional affiliations.

(C) 2020 by the authors. Licensee MDPI, Basel, Switzerland. This article is an open access article distributed under the terms and conditions of the Creative Commons Attribution (CC BY) license (http://creativecommons.org/licenses/by/4.0/). 